\title{
Helicobacter pylori: Epidemiology, diagnosis and clinical relevance
}

\author{
Sander JO Veldhuyzen VAn Zanten, MD, FRCPC, Phil ip M SHerman, MD, FRCPC
}

SJO VELDHUYZEN VAN ZANTEN, PM SHERMAN. Helicobacter pylori: Epidemiology, diagnosis and clinical relevance. Can J Gastroenterol 1993; $7(5): 390-394$. The following aspects of Helicobacter pylori infection are summarized: the epidemiology of $\mathrm{H}$ pylori infection, data on the prevalence of the organism in Canada, methods of diagnosis, and evidence for an association between $\mathrm{H}$ pylori and gastritis, duodenal ulcers, nonulcer dyspepsia and gastric cancer.

Key Words: Duodenal ulcer, Dyspepsia, Gastric cancer, Gastritis, Helicobacter pylori, Urease

\section{Helicobacter pylori: Épidémiologie, diagnostic et pertinence clinique}

RÉSUMÉ: Les aspects suivants de l'infection à Helicobacter pylori sont résumés: l'épidémiologie de l'infection à $H$ pylori, les données sur la prévalence de ce pathogène au Canada, les méthodes diagnostiques, et les preuves d'association entre H pylori et la gastrite, les ulcères duodénaux, la dyspepsie non ulcéreuse et le cancer de l'estomac.

$\mathrm{H}$

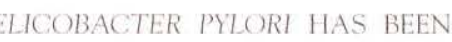
isolated worldwide from the antrum of individuals with chronic active (type B) gastritis. Although $H$ pylori can infect gnotobiotic piglets and nonhuman primates $(1,2)$, humans are the predominant host. The prevalence of $H$ pylori colonization is high even in

Division of Gastroenterology, Victoria General Hospital, Dalhouste University, Halifax, Nova Scotia; and Division of Gastroenterology. The Hospital for Sick Children, University of Toronto, Toronto, Ontario

Correspondence: Dr SJO Veldhuyzen van Zanten, Division of Gastroenterology, Victoria General Hospital, RC Dickson Centre, Room 4086, 1278 Tower Road, Halifax, Nova Scotia B 3 H 2 Y9

asymptomatic populations. Prevalence increases with age, race (ie, higher in black Americans) and lower socioeconomic status $(3,4)$. Of these factors age is the strongest predictor of $H$ pylori infection $(3,5,6)$. In Peru the source of water supply was found to be a risk factor for H pylori infection (7). In developing countries the prevalence is higher than in North America and Western Europe and the infection is acquired at a younger age $(5,6,8)$. The date of acquisition may be important, especially with regard to the possible link that exists with later development of gastric cancers. It is possible that the longer a person has chronic $H$ pylori associated gastritis, the higher the subsequent risk for development of gastric cancer.

The exact mode of transmission of the organism in humans is unclear. There is familial clustering of $\mathrm{H}$ pylori suggesting either a common source of infection or that close personal contact is necessary for transmission of the organism (either oral-oral or fecal-oral) $(9-11)$. Recently, successful culture of $H$ pylori from human feces has been reported (12). In an animal model of gastritis due to helicobacter-like organ- 
isms in the ferret (Helicobacter mustelae), evidence for fecal-oral transmission has also been found (13). In the ferret model hypochlorhydria promotes fecal transmission of $\mathrm{H}$ mustelae (14). This raises the question whether inhibition of gastric acid may make humans more prone to colonization with $\mathrm{H}$ pylori.

Despite the high prevalence of $\mathrm{H} p y$ lori in the general population we do not know the exact timing and source of acquisition in most individuals. A few isolated cases of new onset $H$ pylori colonization have been described (15. 17), which indicate that it can present with an acute upper-gastrointestinal syndrome accompanied by nausea, vomiting and epigastric discomfort. Spontaneous clearance of $H$ pylori infection rarely occurs. Therefore most infected people harbour a lifelong bacterial infection in the gastric antrum.

\section{H PYLORI IN CANADA}

A number of studies have reported on the prevalence of $\mathrm{H}$ pylori in Canada. In children with a mean age of 11 years who underwent endoscopy in Toronto, seven of $67(10 \%)$ were positive for $\mathrm{H}$ pylori in the antrum (18). Of these 67 patients, 49 had normal histological findings as seen on antral biopsies and in eight children histologic evidence of gastritis was explained by Crohn's disease, eosinophilic gastritis or use of medications that are known to cause gastropathy. Of the 10 cases with unexplained antral gastritis, seven children were $H$ pylori positive; this specificity provides support that the organism plays an important role in antral gastritis. In a study of healthy asymptomatic adult volunteers and dyspeptic patients in Toronto, six of $54(11 \%)$ volunteers and 36 of $65(55 \%)$ patients were $H$ pylori positive (19). In dyspeptic adults, who underwent endoscopy in Hamilton, Ontario, the prevalence was $56 \%$ (20). In both these studies H pylori prevalence increased with age. Two large serological studies have been performed, one in blood donors in Manitoba and one in individuals randomly selected from the general population in Nova Scotia $(21,22)$. The results of both studies are comparable and show

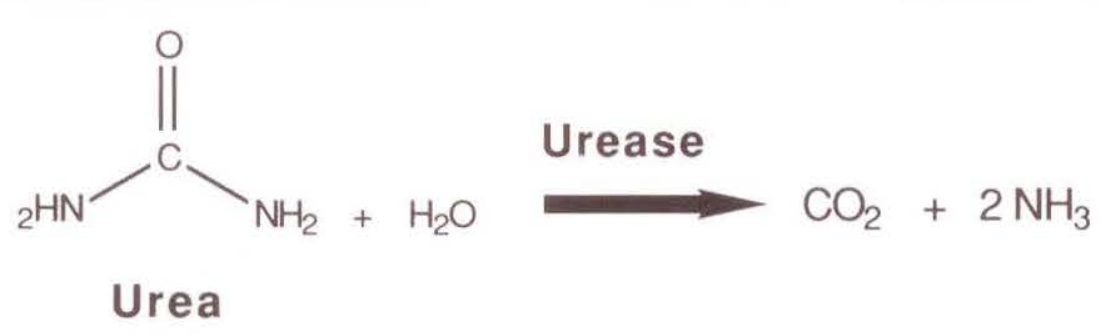

Figure 1) Hydrolysis of urea by the urease enzyme to carbon dioxide and ammonia

that the prevalence of $H$ pylori infection varied from approximately $20 \%$ in 18-year-olds to $50 \%$ in persons over age 70. All these results are similar to the $H$ pylori prevalence rates found in cross sectional studies performed in other affluent countries $(5,6)$.

\section{DIAGNOSIS OF H PYLORI}

Five types of diagnostic tests are currently available: histology, culture, rapid urease testing, ${ }^{13} \mathrm{C}$ - or ${ }^{14} \mathrm{C}$-urea breath tests and serology (eg, enzymelinked immunosorbent assay [ELISA]). Both rapid urease testing (two tests are commercially available in Canada: Campylostat; Intercon Pharma, and CLOrest; Mui Scientific) and the breath test are based upon the very high activity of the urease enzyme, a characteristic feature of the organism $(23,24)$. As shown in Figure 1, the urease enzyme converts urea in the presence of water into carbon dioxide and ammonia. For the rapid urease test a buffered medium is used to which an indicator such as phenol red is added that gives a colour change in an alkaline $\mathrm{pH}$ (in this case by the production of ammonia) $(25-27)$. For the urea breath tests urea is labelled with either ${ }^{13} \mathrm{C}$ or ${ }^{14} \mathrm{C}$ and is administered to the patient together with a test meal. If $H$ pylori organisms are present in the stomach the radiolabelled urea will be converted into ${ }^{13} \mathrm{CO}_{2}$ or ${ }^{14} \mathrm{CO}_{2}$, which can be measured in expired breath samples by either mass spectrometry $\left({ }^{13} \mathrm{CO}_{2}\right)$ or in a scintillation counter $\left({ }^{14} \mathrm{CO}_{2}\right)$ (28. 31).

The urease activity of $H$ pylori is much higher than found in other ureasplitting organisms such as Proteus mirabilis, Proteus vulgaris and Providentia species $(23,32)$. Another difference is that the urease of $\mathrm{H}$ pylori is acid stable whereas urease from other bacterial species such as proteus is acid labile $(32,33)$. The urease of $H$ pylori may therefore offer protection to the organism against destruction by gastric acid.

$H$ pylori is a difficult organism to grow and requires dedicated technicians in the microbiology laboratory in order to obtain reliable results (34). For histological identification several stains are useful: hematoxylin-eosin stain, modified Giemsa and Steiner or Warthin Starry silver stain. In patients not treated with anti-helicobacter therapy it is often possible to recognize $H$ pylori organisms in hematoxylin-eosin stained sections. A careful search for the organism should always be undertaken if there is histological evidence of antral gastritis. After antihelicobacter therapy the number of organisms may be low and additional stains may be required to ensure that eradication of the infection has been achieved.

Several serological assays that measure antibodies against $H$ pylori have been developed (35). These assays use either complement fixation, bacterial agglutination, immunofluorescence, ELISA or flow cytometry to detect H pylori specific immunoglobulin ( $\mathrm{Ig})$ $G$ in serum $(35,36)$. In the initial assays crude antigens, such as whole-cell sonicates, were used but now more purified cell surface antigens, including urease, are available (37-39).

All of the diagnostic tests perform well with a sensitivity of greater than $80 \%$ and a specificity greater than $95 \%$ (20). The operating characteristics of breath tests and serology are slightly better than the other diagnostic tests. This is probably due to the fact that 
these two tests are less prone to sampling error. For practical purposes reli. ahle detection of $H$ polori can he achieved at the time of diagnostic upper gastrointestinal endoscopy by the combination of culture and histology (and rapid urease test if available) of antral hiopsies. In most studies this combination is used as the accepted gold standard to diagnose $H$ pylori infection (40).

The antrum is the most commonly involved portion of the stomach. However, the presence of $H$ pylori may be patchy on the gastric mucosa and the organism missed if only a single biopsy is taken. Therefore, it is recommended that two gastric biopsies are taken at endoscopy for culture and two for histology. This way more than $90 \%$ of infected patients will be identified correctly (20). It is preferable that two biopsies are taken from the antrum and two from the body of the stomach. There are two reasons for this proposal. The new Sydney classification of gastritis recognizes the importance of the dynamics of gastritis that exist between the antrum and body (41). By taking biopsies from both sites the diagnosis of histological gastritis will improve. Second, there is some evidence that after treatment colonization of $H$ pylori may move to the body while at the same time it is difficult to find in the antrum. This has been found, for example, following treatment with the proton pump inhibitor omeprazole (42). There is a poor correlation between the endoscopic appearance of the gastric mucosa and histological presence of gastritis $(18,43)$. Therefore, even if the gastric mucosa looks endoscopically normal it is necessary to ohtain gastric biopsies to determine whether $H$ pylori is present.

\section{CLINICAL RELEVANCE OF H PYLORI}

We recently performed a systematic review of evidence for a causal relationship between $H$ pylori infection and gastritis, duodenal ulcer, gastric cancer and nonulcer dyspepsia (44) and an evaluation by meta-analysis of treatment indications for $H$ pylori infection (45). We refer the interested reader to these publications. In this review we will briefly summarize the evidence for a causal relationship between $H$ pylomi infection and gastritis, duodenal ulcer, gastric cancers and nonulcer dyspepsia.

$H$ pylori as a cause of gastritis: Evidence for a causal link between the presence of the organism and gastritis is fivefold: presence of the organism is invariably associated with histological evidence of gastric inflammation (19, 46-48); eradication of $H$ pylori leads to healing of gastritis (49); self inoculation experiments in human volunteers, who were initially $H$ pylori negative, led to the development of gastritis in the antrum $(50,51)$; outbreaks of epidemic hypochlorhydria are associated with histological gastritis for which $H$ pylori was found to be the hest explanation (52); and prevalence of the organism is low in other forms of gastritis such as eosinophilic gastritis, Crohn's disease and bile reflux $(18,53-55)$. Taken together, these findings fulfil each of Koch's postulates and thereby establish $H$ pylori as the cause of chronic active gastritis in humans.

$H$ pylori and duodenal ulcer: $H$ pylori is now considered to be an important causal factor in the development of peptic ulcers not related to the concurrent use of nonsteroidal anti-inflammatory drugs (NSAIDs) (56). There are five levels of evidence. First, more than $90 \%$ of adult patients with duodenal ulcers are H pylori positive (57). Second, eradication of $H$ pylori results in a lower relapse rate of peptic ulceration $(58,59)$. With the current therapeutic arsenal of $\mathrm{H}_{2}$ receptor antagonists, sucralfate and omeprazole it is easy to heal most ulcers and control them with maintenance treatment. However, discontinuation of maintenance therapy leads to an ulcer relapse rate of up to $85 \%$ at one year of follow-up (60). Bismuth compounds have a convincingly better track record for lower relapse rates of ulcers after a course of treatment $(61,62)$. Possible explanations for this observation are either the anti-helicobacter effect of bismuth compounds or the better quality of healing of the inflamed duodenal and antral mucosa or hoth (63). Third, H pylori relapses before the ul- cer recurs (64). Fourth, heavy colonization with $H$ pylori organisms may be associated with more frequent ulcer relapse (65). Finally, the addition of anti-helicobacter treatment to an $\mathrm{H}_{2}$ blocker accelerates the rate of healing of duodenal ulcers (66). It is important to remember that $H$ pylori infection by itself is not a sufficient cause for development of duodenal ulcers, be cause gastric acid is needed as well (67).

Association with gastric cancer: The role of $\mathrm{H}$ pylori acting as a cofactor for the development of stomach cancers is becoming increasingly clear (68-71). The attributable risk of $H$ pylori infection to gastric cancer is estimated to be as high as $60 \%(68,70)$. It is possible that the risk of gastric cancer is related to the duration of the presence of chronic inflammation in the stomach. A trend towards acquisition of the organism at an older age, as is the case in developed countries, could result in a decrease in the frequency of gastric carcinomas. In Canada the incidence and mortality rates for gastric cancer have declined steadily over the past decades (72).

Association with nonulcer dyspepsia: To date there is no convincing evidence that $H$ pylori plays a role in the subgroup of nonulcer dyspepsia patients that are $H$ pylori positive. The prevalence of $H$ pylori is generally not higher in patients with nonulcer dyspepsia compared with asymptomatic controls $(73,74)$. In addition, there is no difference in symptom severity in Hpylori positive and negative patients suffering from nonulcer dyspepsia (20). Finally, currently there is noevidence that eradication of $H$ pylori leads to an improvement in symptom severity that is superior to placebo (45).

\section{REFERENCES}

1. Krakowka S, Morgan DR, Kraft WG, Leunk RD. Establishment of gastric Campylobacter pylori infection in the gnotobiotic piglet. Infect Immun 1987;55:2789.96.

2. Baskerville A, Newell DG. Naturally occurring chronic gastritis and C pylori infection in the Rhesus monkey: A potential model for gastritis in man. Gut 1988:29:465-72. 
3. Graham DY, Malaty HM, Evans DG, Evans DJ, Klein PD, Adam E. Epidemiology of Helicobacter pylori in an asymptomatic population in the United States. Gastroenterology 1991;100:1495-501.

4. Mendall MA, Goggin PM. Moilineaux N, et al. Childhood living conditions and Helicobacter pylori seropositivity in adult life. Lancet 1992;339:896-7.

5. Megraud F, Brassens-Rebbe MP, Denis F, Belbouri A, Hoa DQ.

Seroepidemiology of Camprlobacter pylori infection in various populations. J Clin Microbiol 1989;27:1870-3.

6. Taylor DN, Blaser MI. The epidemiology of Helicobacter pylori infection. Epidemiol Rev 1991;13:42-59.

7. Klein PD, Graham D), Gaillour A, Opekun AR, O'Brian Smith E. Water source as risk factor for Helicobacter pylori infection in Peruvian children. Lancet 1991;337:1503-6.

8. Mitchell HM, Li YY, Hu PJ, et al. Epidemiology of Helicobacter pylori in Southern China: Identification of early childhood as the critical period for acquisition. I Infect Dis 1992;166:149-53.

9. Drumm B, Perez-Perez Gl, Blaser MJ, Sherman PM. Intrafamilial clustering of Helicobacter pylori infection. N Engl J Med 1990;322:359-63.

10. Perez-Perez G1, Taylor DN, Bodhidatta L, et al. Seroprevalence of Helicobacter pylori infections in Thailand. J Infect Dis 1990;161:1237-41.

11. Malaty HM, Graham DY, Klein P, Evans DG, Adam E, Evans DI. Transmission of Helicobacter pylori infection. Studies in families of healthy individuals. Scand I Gastroenterol 1991;26:927-32.

12. Thomas JE, Gibson GR, Darboe MK. Dale A, Weaver LT. Isolation of Helicobacter pyloni from human faeces. Lancet 1992;340:1 194-5.

13. Fox JG, Paster FE, Dewhirst FE, et al. Helicobacter mustelae isolation from feces of ferrets: Evidence to support fecal-oral transmission of a gastric Helicobacter. Infect Immun 1992;60:606-11.

14. Fox JG, Blanco MC, Yan L, et al. Role of gastric $\mathrm{pH}$ in isolation of Helicobacter mustelae from the feces of ferrets. Gastroenterology 1993;104:86-92.

15. Graham DY, Alpert LC, Lacey Smith J, Yoshimura HH. latrogenic Campylobacter pylori infection is a cause of epidemic hypochlorhydria. Am J Gastroenterol 1988;83:974-80.

16. Frommer DJ, Carrick J, Lee A, Hazell SL. Acute presentation of Campylobacter pylori gastritis. Am ] Gastroenterol 1988;83:1168-71.
17. Sobala GM, Crabtree JE, Dixon MF, et al. Acure Helicobacter prloni infection: Clinical features, local and systemic immune response, gastric mucosal histology, and gastric juice ascorbic acid concentrations. Gut 1991:32:1415-8.

18. Drumm B, Sherman PM, Cutz E, Karmali M. Association of Campylobacter pylori on the gastric mucosa with antral gastritis in children. N Engl J Med 1987;316:1557-61.

19. Gregson DB, Low DE, Cohen M, et al. The prevalence of Campylobacter pylori gastritis among asymptomatic adults. Can Med Assoc J 1989;140:1449-53.

20. Veldhuyzen van Zanten SJO, Tytgat KMAJ, de Gara CJ, et al. A prospective comparison of symptoms and five diagnostic tests in patients with Helicobacter pylori positive and negative dyspepsia. Eur J Gastroenterol Hepatol 1991;3:463-8.

21. Perez-Perez Gl, Marrie T, Inouye H, et al. The effect of age and occupation on the seroprevalence of Helicobacter pylori infection. Can J Infect Dis 1992;3:134-8.

22. Veldhuyzen van Zanten SJO, Best L, Bezanson G, Haldane D, Marrie TM. A prospective two and three year follow-up of seroconversion of Helicobacter pylori in a randomly selected population. Gastroenterology 1992;102:184. (Abst)

23. Mobley HLT, Cortesia M], Rosenthal LE, Jones BD. Characterization of urease from Campylobacter pylori. J Clin Microbiol 1988;26:831-6.

24. Hawt in PR, Stacey AR, Newell DG. Investigation of the structure and localization of the urease of Helicobacter pyleri using monoclonal antibodies. J Gen Microbiol 1990;136:106-11.

25. Marshall BJ, Warren JR, Francis G], et al. Rapid urease test in the management of Campylobacter pylori associated gastritis. Am J Gastroenterol 1987;82:200-10.

26. Hazell SL, Borody TJ, Gal A, Lee A. Campylobater pylomi gastrit is I:

Detection of urease as a marker of bacterial colonization and gastritis. Am J Gastroenterol 1987:82:292-6.

27. Goldie J, Veldhuyzen van Zanten SJO, Jalali S, et al. Optimisation of a medium for the rapid urease test for detection of Campylobacter pylori in gastric antral biopsies. J Clin Microbiol 1989:27:2080-2.

28. Graham DY, Klein PD, Evans DJ, et al. Campylobacter pylori detected noninvasively by the ${ }^{13} \mathrm{C}$-urea breath test. Lancet 1987;i:1174-7.

29. Bell GD, Weil J, Harrison G, et al.
${ }^{14} \mathrm{C}$-urea breath analysis, a non-invasive test for Campylohacter pylomi in the stomach. Lancet 1987;i:1367-8.

30. Marshall BI, Surveyor 1, Carbon-14 urea breath test for the diagnosis of Campylobacter pylori associated gastritis. I Nud Med 1988:29:11-6.

31. Veldhuyzen van Zanten SJO, Tytgat KMAJ, Hollingsworth I, et al.

${ }^{14}$ C. Urea breath test for the detection of Campylohacter pylori. Am J Gastroenterol 1990;85:399-403.

32. Ferreto RL, Lee $A$. The importance of urease in acid protection for the gastric-colonizing bacteria Helicobacter pylori and Helicobacter felis sp nov. Microb Ecol Health Dis 1991:4:121-34.

33. Segal ED, Shon J, Tompkins LS. Characterization of Helicobacter prlomi urease mutants. Infect Immun 1992;60:1883-9.

34. Goodwin S, Blincow ED, Warren JR, Waters TE, Sanderson CR, Easton L. Evaluation of culture techniques for isolating Campylobacter pyloni from endoscopic biopsies of gastric mucosa. J Clin Pathol 1985;38:1127-31.

35. Newell DG, Stacey AR. The serology of Campylobacter pylori infections. In: BJ Rathbone, RV Heatley, eds. Campylobacter pylori and Gastroduodenal Disease. Oxford: Blackwell Scientific Publications, 1989:74-82.

36. Best LM, Veldhuyzen van Zanten SJO, Bezanson GS, et al. Serological detection of Helicobacter pylori by flow microsphere immunofluorescent assay (FMIA). I Clin Microbiol 1992;30:2311-7.

37. Evans DJ, Evans DG, Graham DY, Klein PD. A sensitive and specific serologic test for detection of Campylobacter pylori infection. Gastroenterology 1989;96:1004-8.

38. Sugiyama T, Imai K, Yoshida $H$, et al. A novel enzyme immunoassay for serodiagnosis of Helicobacter pylori infection. Gastroenterology 1991;101:77-83

39. Dunn BE, Campbell G, Perez-Perez GI, Blaser MI. Purification and characterization of urease from Helicobacter pylori. J Biol Chem 1990;265:9464-9.

40. Graham DY, Borsch GMA. The who's and when's of therapy for Helicobacter pylori. Am J Gastroenterol 1990:85:1552-5.

41. Price AB. The Sydney system: Histological division. Eur J Gastroenterol Hepatol 1991;6:209-22.

42. Logan RP, Gummett PA, Walker MM, Polson RJ, Baron JH, Misiewicz JJ. Does omeprazole affect Helicobacter pylori? Eur J 
Gastroenterol Hepatol 1991;3:S10. (Ahst 37)

43. Sauerbruch T, Schreiher MA, Schussler P, Permanetter W.

Endoscopy in the diagnosis of gastritis. Diagnostic value of endoscopic criteria in relation to histological diagnosis. Endoscopy 1984:16:101-4.

44. Veldhuyzen van Zanten SJO, Sherman PM. Treatment indications for Helicobacter pylort infection: A meta-analysis. Can Med Assoc J. (Submitted for publication)

45. Veldhuyzen van Zanten SJO, Sherman PM. Helicobacter pylori infection as the cause of gastritis, duodenal ulcer, gastric cancer and non-ulcer dyspepsia. A meta-analysis. Can Med Assoc I.

(Submitted for publication)

46. Blaser MJ. Gastric campylobacter-like organisms, gastritis, and peptic ulcer disease. Gastroenterology 1987;93:371-83.

47. Barthel JS, Westblom U, Havey AD, Gonzalez F, Everett D. Gastritis and Campylobacter pylori in healthy asymptomatic volunteers. Arch Intern Med 1988;148:1149-51.

48. Dooley CP, Cohen H, Fitzgibbons PL, et al. Prevalence of Helicobacter pylori and histologic gastritis in asymptomatic persons. N Engl J Med 1989;321:1562-6.

49. Rauws EJ, Langenberg W, Houthoff HI, Zanen JC. Tytgat GNJ. Campylobacter pyloridis-associated chronic active antral gastrit is. Gastroenterology 1988;94:33-40.

50. Marshall BJ, Armstrong JA, McGechie DB, Glancy RI. Attempts to fulfill Koch's postulates for pyloric campylobacter. Med J Aust 1985;142:436-9.

51. Morris A, Nicholson G. Ingestion of Campylobacter pylori causes gastrit is and raised fasting gastric $\mathrm{pH}$. $\mathrm{Am}$ ] Gastroenterol 1987;82:192-9.

52. Hunt RH. Campylobacter pylori and spontaneous hypochlorhydria. $[\mathrm{n}$ : B] Rathbone, RV Heatley, eds. Campylobacter pylori and
Gastroduodenal Disease. Oxford: Blackwell Scientific Publications, 1989:176-84.

53. Ormand JE, Talley NJ, Shorter RG, et al. Prevalence of Helicobacter pylori in specific forms of gastritis. Dig Dis Sci 1991;36:142-5.

54. O'Connor H], Newbold KM, Alexander-Williams J, et al. Effect of Roux-en- $Y$ anastomosis on Campylobacter pylori. Gastroenterology 1989;97:958-64.

55. Drumm B, O'Brien A, Cutz E, Sherman P. Campylobacter pyloridis-associated primary gastritis in children. Pediatrics 1987;80:192-5.

56. Tytgat GNJ, Axon ATR, Dixon MF, Graham DY, Lee A, Marshall B]. Helicobacter pylori: Causal agent in peptic ulcer disease? Working Party Reports. World Congress of Gastroenterology. Oxford: Blackwell Scientific, 1990:36-45.

57. Tytgat GNJ, Rauws EAJ. Campylobacter pylori and its role in peptic ulcer disease. Gastroenterol Clin North Am 1990;19:183-96.

58. Marshall BJ, Goodwin CS, Warren JR, et al. Prospective double-blind trial of duodenal ulcer relapse after eradication of Campylohacter pylori. Lancet 1988;ii:1437-42.

59. Rauws EJ, Tytgat GNJ. Cure of duodenal ulcer disease associated with eradication of Helicobacter prlori. Lancet 1990;335:1233-5.

60. Miller JP, Faraghar EB. Relapse of duodenal ulcer: Does it matter which drug is used as initial treatment? Br Med J 1986:293:1117-8.

61. Dobrilla G, Vallaperta P, Amplatz S. Influence of ulcer healing on ulcer relapse after discontinuation of acute treatment: A pooled estimate of controlled trials. Gut 1988;29:181-7.

62. Miller JP, Faragher EB. The potential impact of Campylobacter pylori on the treatment of duodenal ulcer disease. Scand J Gastroenterol 1989:24:39-45.

63. Pan S, Liao CH, Lien GS, Chen SH. Histological maturity of healed duodenal ukers and uker recurrence after treatment with colloidal bismuth subcitrate or cimetidine. Gastroenterology 1992;101:1187-92.

64. Logan RPH, Gummett PA, Polson RJ, et al. The recurrence of $H$ pylori in relation to duodenal ulcer. Rev Esp Enf Digest 1990;78(Suppl I):72. (Abst 152)

65. Hui WM, Ho J, Lam SK. Pathogenetic role of Helicobacter pylori in duodenal ulcer disease. Multivariate analysis of factors affecting relapse. Dig Dis Sci 1991;36:424-30.

66. Graham DY, Lew GM, Evans DG, Evans DJ, Klein P. Effect of triple therapy (antibiotics plus bismuth) on duodenal ulcer healing. A randomized controlled trial. Ann Intern Med 1991;115:266-9.

67. Graham DY. Campylobacter pylomi and peptic ulcer disease. Gastroenterology 1989;96:615-25.

68. Forman D, Newell DG, Fullerton F, et al. Association between infection with Helicohacter pylori and risk of gastric cancer: Evidence from a prospective study. Br Med J 1991;302:1302-5.

69. Nomura A, Stemmerman GN, Chyou $\mathrm{PH}$, et al. Helicobacter pylori and gastric carcinoma among Japanese Americans in Hawaii. N Engl J Med 1991;325:1132-6.

70. Parsonnet J, Friedman G, Vandersteen DP, et al. Helicobacter pylori and the risk of gastric carcinoma. $\mathrm{N}$ Engl J Med 1991;325:1127-31.

71. Correa P. Is gastric carcinoma an infectious disease? N Engl ] Med 1991;325:1170-1.

72. Canadian Cancer Statistics 1988. Canadian Cancer Society, 1988.

73. Bernerson B, Johnsen R, Bostad L, Straume B, Sommer AI, Burhol PG. Is Helicobacter pylori the cause of dyspepsia? Br Med J 1992;304:1276-9.

74. Nyren O. Functional dyspepsia: Is gastric acid and/or Helicobacter pylori infection involved in the aetiology? Eur J Gastroenterol Hepatol 1992;4:608-14. 


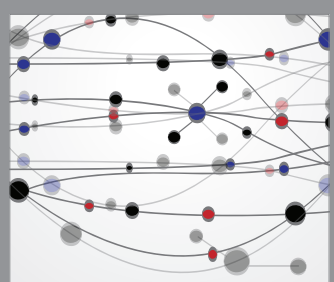

The Scientific World Journal
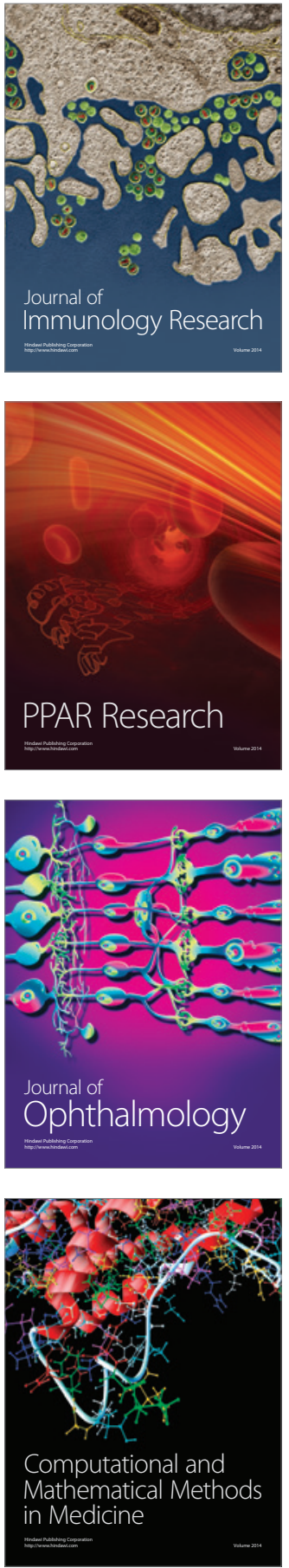

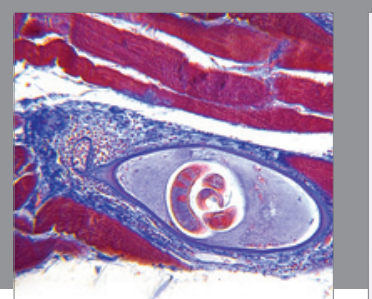

Gastroenterology Research and Practice

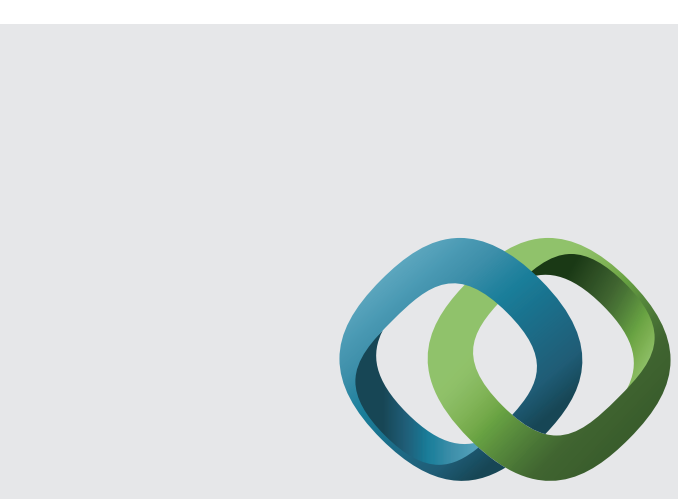

\section{Hindawi}

Submit your manuscripts at

http://www.hindawi.com
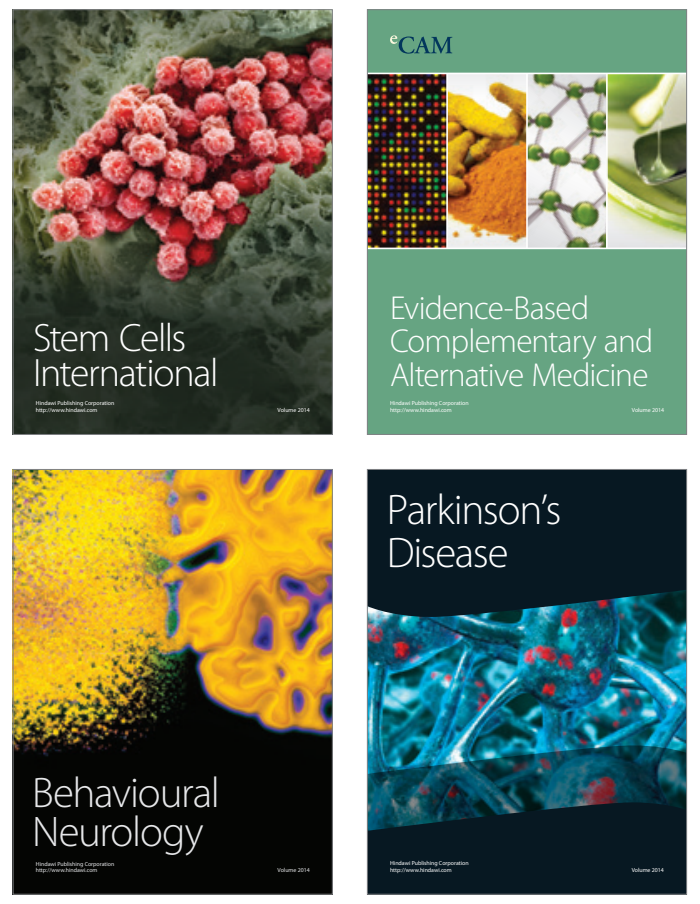
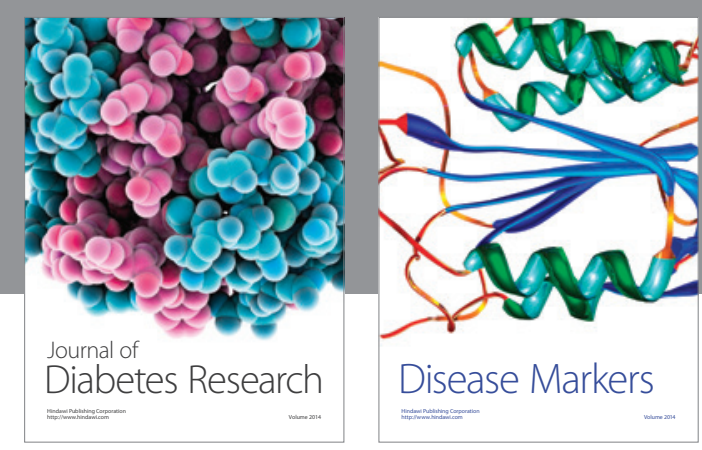

Disease Markers
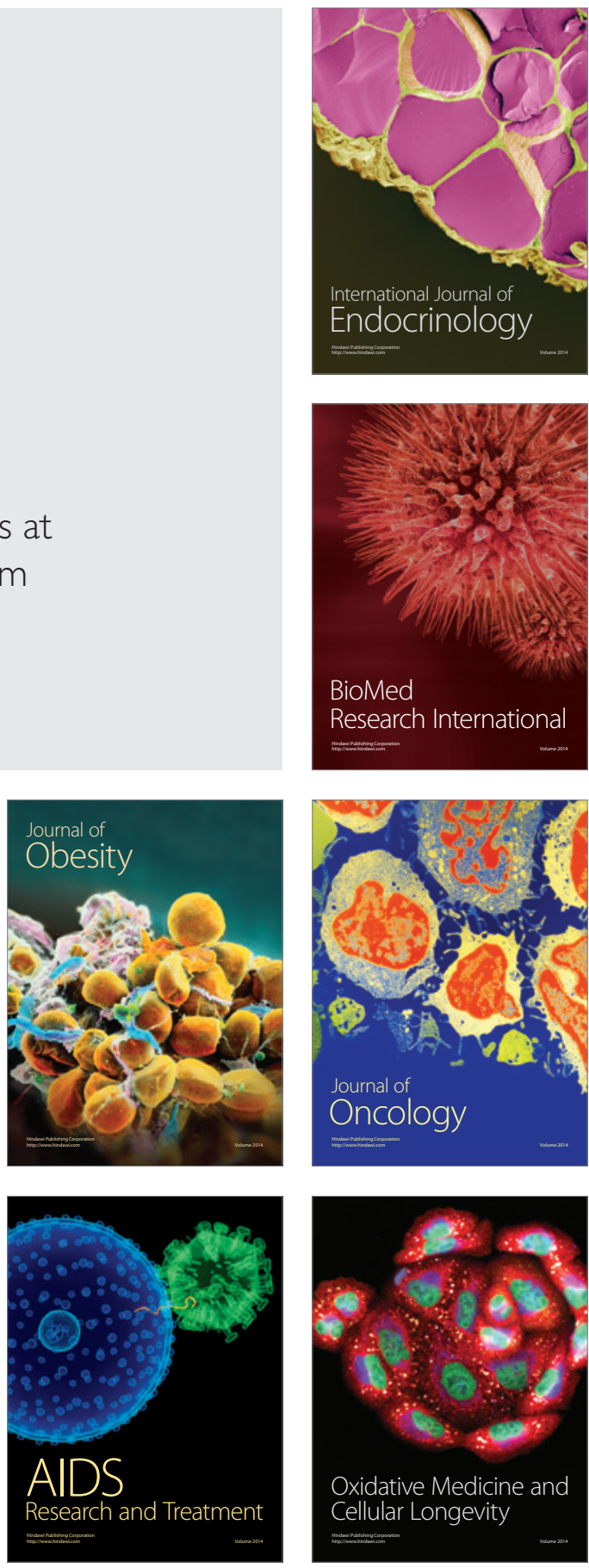